DOI: $10.22559 /$ folklor.950

Folklor/edebiyat, cilt:25, say1: 97-1, 2019/1

\title{
Sosyal Duygusal Öğrenme Çerçevesinde Öz Düzenleme Yabancı Dil Öğrenme Ölçeğinin Geliştirilmesi
}

\section{Development of a Self- Regulation Foreign Language Learning Scale Within the Framework of Social Eotional Learning}

\begin{abstract}
Senem Zaimoğlu* Şehnaz Şahinkarakaş**

Abstract

A growing body of research underlines the significance of self-regulation in foreign language learning (Dörnyei, 2005; Oxford, 2011; Chamot, 2014). In line with this, researchers have developed numerous instruments to help learners deal with the challenge of language learning. However, these instruments have been generally designed within the framework of language learning strategies not within the framework of social and emotional learning (SEL). From this point of view, the current study tries to fill this gap by developing an appropriate instrument to assess university students' self-regulatory competences in foreign language learning within the framework of SEL. Moreover, the effects of gender on language learners' self-regulatory competences were also examined by using structural equation model. Data was gathered using three different samples of 1439 preparatory school students from a university in total. Principal component analysis of the Self-Regulation Foreign Language Learning Scale (SRFLLS) yielded an eight-factor structure: Recognition of Strengths and Emotions, Self-Efficacy, Emotional Costs, Self-Motivation, Self-Discipline, Goal-Setting, Help-Seeking and Curiosity. In accordance with confirmatory factor analyses, it was observed that the model fit indices were acceptable and there was a significant difference based on gender in language learners' self-regulatory competences of Self-Discipline, Help-Seeking and Curiosity. Limitations and directions for future research are discussed.
\end{abstract}

Key words: Self-Regulation, Social and Emotional Learning (SEL), Social and Emotional Competence (SEC), scale development, scale validation

\footnotetext{
* Çă̆ University, English Language Teaching Department, senemdag@ cag.edu.tr

** Prof. Dr., Çağ University, English Language Teaching Department, sehnazkarakas@ @ag.edu.tr
} 
$\ddot{O} \mathbf{z}$

Sayısı her geçen gün biraz daha artan araştırmalar, yabancı dil öğreniminde öz-düzenlemenin önemini vurgulamaktadır (Dörnyei, 2005; Oxford, 2011; Chamot, 2014). Bu araştırmalar doğrultusunda, araştırmacılar, öğrencilerin dil öğrenimindeki zorluklarla başa çıkmalarına yardımcı olmak için çok sayıda araç geliştirmişlerdir. Ancak, bu araçlar genellikle sosyal ve duygusal öğrenme çerçevesinde değil, dil öğrenme stratejileri çerçevesinde tasarlanmıştır. Bu açıdan bakıldığında, bu çalışma, üniversite öğrencilerinin yabancı dil öğrenirken, sosyal ve duygusal öğrenme çerçevesinde öz-düzenleme yetkinliklerini belirlemek için uygun bir araç geliştirerek bu boşluğu doldurmaya çalışmaktadır. Ayrıca, cinsiyetin dil öğrenenlerinin öz-düzenleme yetkinlikleri üzerindeki etkileri de yapısal eşitlik modeli kullanılarak incelenmiştir. Ölçeklerin faktör yapısı ve iç tutarlılığıyla ilgili veriler üç farklı zamanda toplam olarak da bir üniversitenin 1439 hazırlık okulu öğrencisine uygulanarak toplanmıştır. ÖzDüzenleme Yabancı Dil Öğrenme Ölçeğinin (SRFLLS) temel bileşen analizi, sekiz faktörlü bir yapı ortaya koymuştur: Güçlü Yönlerin ve Duyguların Tanınması, Öz-yeterlilik, Duygusal Bedeller, ÖzMotivasyon, Öz Disiplin, Hedef Belirleme, Yardım Arama ve Merak. Cevapların doğrulayıcı faktör analizlerine göre ise, model uyum değerlerinin kabul edilebilir olduğu ve cinsiyete bağlı olarak dil öğrenenlerin Öz-disiplin, Yardım Arama ve Merak yeterliliklerinde anlamlı bir farklılık olduğu gözlemlenmiştir. Çalışma sınırlamaları ve gelecekteki araştırmalar için açıklamalar ele alınmıştır.

Anahtar sözcükler: Öz-Düzenleme, Sosyal ve Duygusal Öğrenme, Sosyal ve Duygusal Yetkinlik; ölçek geliştirme; ölçek doğrulaması

\section{Introduction}

There has been a considerable change in society and the life experiences of students during the last century. The economic and social pressures on families, the overuse of internet by the students in social networking, tweeting, texting messages, instant messaging, music and video download are some of the reasons for this change (Greenberg et al., 2003). As a result, they experience some problems in their academic life such as not being able to give attention to anything.

In this learning context for the $21^{\text {st }}$ century, the need for social and emotional learning (SEL) emerges because this model of learning not only enhances students' performance but also prepares them to cope with the difficulties in their academic life such as overcoming ambiguous situations, managing stress, finding ways about how to learn and develop themselves, establishing positive relationships, making effective decisions and successful choices. In line with this, many researchers have tried to define the important skills and competences underlying SEL (Kagan, Moore, \& Bredekamp, 1995; CASEL, 2005; Coryn, Spybrook, Evergreen \& Blinkiewicz, 2009; Durlak, Weissberg, Dymnicki, Taylor \& 
Schellinger, 2011). However, in each study, there were some terminological differences in the classification of the social and emotional skills. Halle and Darling-Churchill (2016) revised all these studies and defined four common subdomains in relation to SEL, one of which is SelfRegulation, the ability to change and draw one's attention to a social situation when needed, enliven and forbid behavior when required, and regulate the behaviors and emotions in social interactions (Schunk \& Zimmerman, 1998). This premise is based on Bandura's social cognitive learning theory (1986), which underlines the importance of the mutual interactions among environmental factors, personal processes, and behaviors for human functioning. With respect to this view, the agency of the learner comes into prominence. The learner makes some choices and shapes his/her way of learning considering these choices to reach his/her goals, which underpins self-regulated learning (SRL).

SRL is also very important when students at the university context are considered because the transition from high school to university is one of the biggest events in students' life. While most students are excited about the greater freedom they will enjoy, eager to make new friends and explore new and exciting experiences beyond their hometown, the reality of studying at the university quickly emerges for many as an over-excitement, anxiety, confusion, fear, and stress. These negative emotions arise from students' not adapting themselves to changes such as leaving their family, moving to a new area, being a part of a new social network, and what is more important facing unfamiliar academic studies such as foreign language learning. When students start their foreign language education, they experience the emotional and practical challenges such as feeling disconnected with the school, not getting used to learning a foreign language that may be more challenging than anticipated, comparing oneself to other students and becoming discouraged, and having difficulty managing relationships. It is really difficult for them to overcome all these challenges. While some of the students give up their education, some of them strive for being successful. In that case, teachers have an important role to help students overcome these negative feelings through not only establishing social interactions and relationships but also integrating self-regulation skills, a part of the SEL practices, which enables students to cope with the challenges that they face in learning a foreign language (Zimmerman, 1990). However, these practices are often neglected at universities as students at the university level are thought to have the needed skills necessary for their future. The thing is some university students still do not recognize their own emotions, interests, thoughts and their impact on behaviours. Therefore, they cannot describe and understand their 
own emotions, weaknesses and strengths (Payton et al., 2000). Moreover, they cannot control their emotions, behaviours and thoughts under difficult situations.

From this perspective, self-regulation has a great impact on learners' progress not only academically but also socially and emotionally at the university. However, the instruments developed to understand learners' self-regulated capacity in foreign language learning have been generally designed within the framework of language learning strategies not within the framework of SEL. From this point of view, this study tries to fill this gap by developing an appropriate instrument to assess university students' self-regulation competences while learning a foreign language within the framework of SEL.

\section{Self-regulation in social emotional learning}

SEL defined by Collaborative for Academic, Social, and Emotional Learning (CASEL) is the educational process of enhancing students' knowledge, skills and behaviors (Payton et. al, 2000; CASEL, 2003). However, many students do not have the necessary social-emotional capacities and as a result they become less interested in the daily interactions in the classrooms. In order to develop these capacities, both teachers and students need to work together supporting each other because social-emotional skills and competences are necessary for students' participation in learning practices, students' learning capacity enhancement and academic achievement. With the help of these supportive relationships, social-emotional learning emerges, which is challenging, meaningful and engaging (CASEL, 2003).

CASEL (2013) identifies five core interrelated sets of cognitive, affective, and behavioral competences associated with SEL, which are self-awareness, social-awareness, selfmanagement, relationship skills and responsible decision making. 21st century skills were also included under these categories, some of which are critical thinking, problem solving, adaptability, initiative and entrepreneurialism, creativity, curiosity and imagination. In this case, the question that comes to mind is how self-regulation is in connection with SEL competences including $21^{\text {st }}$ century skills.

When SEL competences are taken into account, self-regulation overlaps extensively with the competences of self-awareness and self-management as self-regulated learners take an active role in learning by setting goals and they overcome obstacles by using the most suitable strategies to realize these goals. Moreover, they can recognize own strengths, needs and seek help when they need to maximize their learning (Zimmerman, 2002), which are all related to 
self-awareness and self-management competences. From this point of view, it can be said that self-regulation harbors two competences of SEL. In terms of the 21 st century skills, Wolters (2010) states that self-regulated learning also overlaps with the $21^{\text {st }}$ century skills of initiation, self-direction and adaptability. For example, a self-regulated learner sets learning goals, selfmanages the effective pursuit of these goals and works independently to accomplish the goals as in the $21^{\text {st }}$ skills of initiation and self-direction. The 21 st century skill of adaptability including the ability to make use of the feedback effectively shows similarities with the monitoring and reflection phases of self-regulated learning. Self-regulated learners are capable of using different forms of feedback to be successful in learning activities (Wolters, 2010). All in all, self-regulation has an important role in SEL as it comprises some SEL competences and $21^{\text {st }}$ century skills, which enables learners to progress in their foreign language learning.

\section{Method}

SRFLLS is a survey designed to assess how university students are aware of themselves as well as others and how they manage requirements throughout their lifetime such as improving learning capacity, setting goals, seeking help when needed, and recognizing emotions and strengths. In order to develop SRFLLS scale, the basic criteria for the development of a valid and reliable questionnaire were followed. The relevant literature on selfregulated learning, self-regulation skills and strategies was examined. This body of literature, scrutinized earlier, formed a theoretical basis for item construction in the questionnaire. The existing instruments designed to evaluate SRL provided information in terms of the survey style, approach and item generation. These items needed to represent the important aspects of SRL and measure of self-regulation skills accurately.

Taking all these issues into account, an original item pool regarding the content of selfregulation was formed and the necessary improvements were made. This item pool was based on the relevant literature and students' answers to open-ended questions about the selfregulation skills in foreign language learning. In addition to that, experts' opinions were taken into consideration and the number of items was reduced or the items were improved in line with the suggestions of those experts. Then, the scale was administered to university students to test the research instrument, SRFLLS, by means of two phases of piloting before starting actual data collection in the 2016-2017 Academic Year. After the pilot studies, the scale was conducted to university students in the 2017-2018 Academic Year to confirm the prior findings of internal consistency. All in all, a total of 1439 students participated for the development of 
the scale. The age range of the students in the study was between 17 and 23. Although these students were all learning English in the preparatory program of a university, they were from different departments such as International Trade, Law, International Relations, Management, Psychology, Finance and Applied Translation and coming from different parts of Turkey, which increased diversity in response types. The students were given clear instructions with regard to filling out the questionnaire and they were assured that their responses would be confidential and they would be used for academic purposes. The questionnaire including the demographic question section was administered anonymously. Students rated each item using a 5-point Likert scale ranging from 1 (strongly disagree) to 5 (strongly agree).

In terms of the scales, a series of psychometric analyses including exploratory factor analysis, item-total correlations, reliability analysis, confirmatory factor analysis, and structural equation modeling were performed, which were explicated in Findings and Discussion Part. This study grounds on Hair, Black, Babin, and Anderson's (2010) suggestions in terms of the perfect and acceptable values for goodness of fit indices.

\section{Results}

\section{Phase 1}

In the item generation, all skills related to self-awareness and self-management competences in SEL and $21^{\text {st }}$ century skills were searched extensively in the literature. Besides this, 25 students were asked to fill out an open-ended questionnaire consisting of 25 questions related to students' self-regulated competences. Students' answers to the open-ended questionnaire were categorized and also written as an item addition to the findings in the literature. Four teachers experienced in language teaching revised all items in an iterative process and then the items were sent to two native teachers who were familiar with the competences. Using these constructs as a guide, a comprehensive list of 113 items was generated. These teachers were also encouraged to provide comments and suggestions for each item. The researcher reviewed the suggestions and made revisions to several items. A total of 10 items were deleted from the initial pool as they did not have any connection with the selfregulated competences within SEL. Consequently, the instrument contained 103 items for assessing university students' self-regulated competences in keeping with CASEL categorizations, which are self-awareness and self-management. It is worth mentioning that 21 st century skills were also included under these categories, some of which are critical thinking, problem solving, self-direction, adaptability, leading by influence, initiative and 
entrepreneurialism, creativity, curiosity and imagination. What is more important is that these categories also formed the basis for item development.

In terms of the language of the items, the chosen items were translated into Turkish by two different faculty members experienced in their fields. The translators were chosen very carefully to provide the equivalence of the translation with the original text. Then, two experts in English specialized in the field of language translation made back-translation from Turkish to English. Moreover, the revision of the translations was carefully made by taking the opinions of two different English teachers. Then, the wording of the items was controlled to understand if there were any negative statements in the tool. The negatively worded statements were recorded before calculating the composite scale scores. After all these processes, the initial scale was ready for implementation to 647 students enrolled at a University Preparatory School context in the 2016-2017 Academic Year.

Basic statistics calculations were performed after administering the results of initial scale. Quantitative research methods were implemented in order to assess the extent of the validity and reliability of the instruments. Moreover, the Cronbach's alpha reliability technique was used for 103-item scale to understand its internal consistency. The reliability estimate for the initial scale (SRFLLS) was 0.80. Considering the ordinal nature of the data in the first-pilotphase, this reliability coefficient for the sample was within acceptable limits. Moreover, the scale was subjected to a combination of reliability analysis by giving attention to item-to-item correlations and initial field testing (exploratory factor analysis) with varimax rotation and Kaiser Normalization. In the factor analysis, a series of meticulous analyses were done to develop a good instrument. For this analysis, as a first step, a factor analysis was run on the items within each subscale to identify the covariation among the items. As a result of factor analysis, numerous factors were identified. Questionable items which calculated at less than 0.40 were identified as a result of item-to-total correlations. Then, the factor loadings of these items were examined in accordance with the factor analysis and items which loaded weakly were deleted from the scale. As a result, 35 out of 103 items were deleted from the questionnaire at the end of the first phase of the study.

\section{Phase 2}

In the second phase of the study, there were only 68 items left to be conducted to 182 university students in the 2016-2017 Academic Year. These items consisting of main categories of SRL were reviewed by experienced teachers to get more opinions about the items (Dornyei, 
2003). Quantitative research methods were again used to assess the extent of the validity and reliability of the instruments using Cronbach's alpha reliability technique. All 68 items were exposed to principal components analyses with varimax rotation. As a result of these analyses, numerous factors were identified. In order to identify the problematic items, their factor loadings were again examined. The problematic items were deleted from the scale. After this, the wording of a few items was changed based on the experts' opinions to clarify the items. Moreover, long statements were split into smaller ones or changed into two different items and some more items were added. Then, principal components analysis of standardized item scores was carried out. In accordance with the scree plot examination and item-loading patterns, the clearest interpretation of the data was provided with an eight-factor solution including 48 items, which were Recognition of Strengths and Emotions, Self-Efficacy, Emotional Costs, SelfMotivation, Self-Discipline, Goal-Setting, Help-Seeking and Curiosity. The factor loadings of the items ranged from 0.45 to 0.85 . Moreover, its overall Cronbach's alpha internal consistency reliability coefficient was computed and the result, 0.85 , indicated that the items had high internal consistency.

When these factors were examined, it was observed that factor 1 consisted of 6 items with factor loadings ranging from .85 (I am curious about discovering new things) to .45 (I am curious about learning new languages). Item analysis suggested that factor 1 is measuring students' desire for new information and knowledge and their general interest in gaining new information to improve themselves. Based on this, this factor was labeled as Curiosity. Factor 2 consisted of 10 items with factor loadings ranging from .88 (I cannot control my feelings when I get angry) to .46 (I do not mind reflecting my feelings while learning English). This factor shows the importance of students' ability to accurately assess their strengths, emotions, limitations with a well-grounded sense of confidence and optimism. Therefore, it was labeled as Recognition of Emotions and Strenghts. It should be noted that some items in this factor are negatively worded. As a result, they were reverse scored. Factor 3 consisted of 6 items with factor loadings ranging from .85 (I can do even the hardest homework if I try) to .60 (I know there are things that I can get better on). This factor underlined the importance of "students' belief about their capabilities to produce designated levels of performance that affect their lives" (Bandura, 1994, p. 1). Therefore, it was labeled as Self-Efficacy. Five items with factor loadings ranging from .80 (I am scared when I do not know how to do something) to .46 (Asking questions in the class makes me feel uncomfortable) loaded on to Factor 4. In contrast to factor 3 , these items deal more directly with the potential negative emotional impacts of students in 
the learning context such as fear, vulnerability and shyness. Several items measure students' avoidance of situations in their foreign language learning. For this reason, this factor was titled as Emotional Costs. Factor 5 was loaded by 5 items with factor loadings ranging from .84 (I can easily motivate myself when I fail) to .75. (I can motivate myself when I face a difficult situation). Item analysis suggested that this factor represents students' positive energy that triggers their involvement in learning activities when they face with negative situations in their learning. This factor was labeled as Self-Motivation. Factor 6 consisted of 5 items with factor loadings ranging from .67 (I overcome difficulties) to .46 (I concentrate on learning new skills while learning English). The items represent the ability to control desires and impulses to successfully reach a goal so this factor was labeled as Self-Discipline. Factor 7 was loaded by 7 items with factor loadings ranging from .84 (I shape my life in accordance with my goals) to .68 (The challenges I face never stop me to achieve my goals). The items represent the ability to set, work and behave toward personal and academic goals. They are directly-stated items. Just looking at the explanation of the items, it is easy to name the factor as Goal-Setting. The last factor consisted of 5 items with factor loadings ranging from .82 (I get my teachers to help me if I do not understand the lesson) to .64 (I get my family to help me when I have social problems). The items in this factor represent students' need for help when they have problems so this item was labeled as Help-Seeking.

Later, the 48-item SRFLLS was evaluated through confirmatory factor analysis. After examining of the modification indices of the CFA analysis for each dimension, four items from the "Goal-Setting" dimension, six items from the "Recognition of Emotions and Strengths" dimension, three items from the "Self-Efficacy" dimension, two items from the "Help-Seeking" dimension, three items from the "Curiosity" dimension, two items from the "Self-Motivation" dimension, one item from the "Self-Discipline" dimension and two items from the "Emotional Costs" dimension were deleted. The CFA was re-examined on the remaining 25 items which resulted in sound fitness of the model as shown in Figure 1. In addition to them, exploratory factor analysis was conducted again with 25 -item scale. The factor loadings ranged from .54 to .89 as shown in Figure 1.

In order to confirm the prior findings of internal consistency, this 25 -item scale was conducted to 610 university students in the 2017-2018 Academic Year. The crosscheck of internal consistency revealed Cronbach's alpha being .82, .77, .76, .90,.70, .87, .73, and .85 for Recognition of Strengths and Emotions, Self-Efficacy, Emotional Costs, Self-Motivation, Self-Discipline, Goal-Setting, Help-Seeking and Curiosity respectively. 
Table 1. The Effects of Gender on the Eight Dimensions of the SRFLLS

\begin{tabular}{llll}
\hline Dimension & $\beta$ & SE & $\mathrm{p}$ \\
\hline Strenghts \& Emotions & .16 & .04 & .12 \\
Self-Efficacy & .03 & .03 & .17 \\
Emotional Costs & .10 & .06 & .14 \\
Self-Motivation & .15 & .07 & .18 \\
Self-Discipline & .12 & .07 & .001 \\
Goal-Setting & .13 & .03 & .15 \\
Help-Seeking & .09 & .02 & .03 \\
Curiosity & .02 & .05 & .02 \\
\hline
\end{tabular}

The last step was to understand the effects of gender on the eight dimensions of SRFLLS. In order to model this effect, gender was used as the predictor and its effects on selfmotivation, self-discipline, emotional costs, help-seeking, goal-setting, strenghts and weaknesses recognition, self-efficacy and curiosity were checked in a structural equation model. As gender is a dichotomous predictor, male was coded as 1 , and female as 2 in the analysis. In accordance with the results as shown in Table 1, there is a significant difference between female and male students in self-discipline $(\beta=.12, \mathrm{p}=.001)$, help-seeking $(\beta=.09, \mathrm{p}=$ $.03)$ and curiosity $(\beta=.02, \mathrm{p}=.02)(\mathrm{p}<0.05)$. 


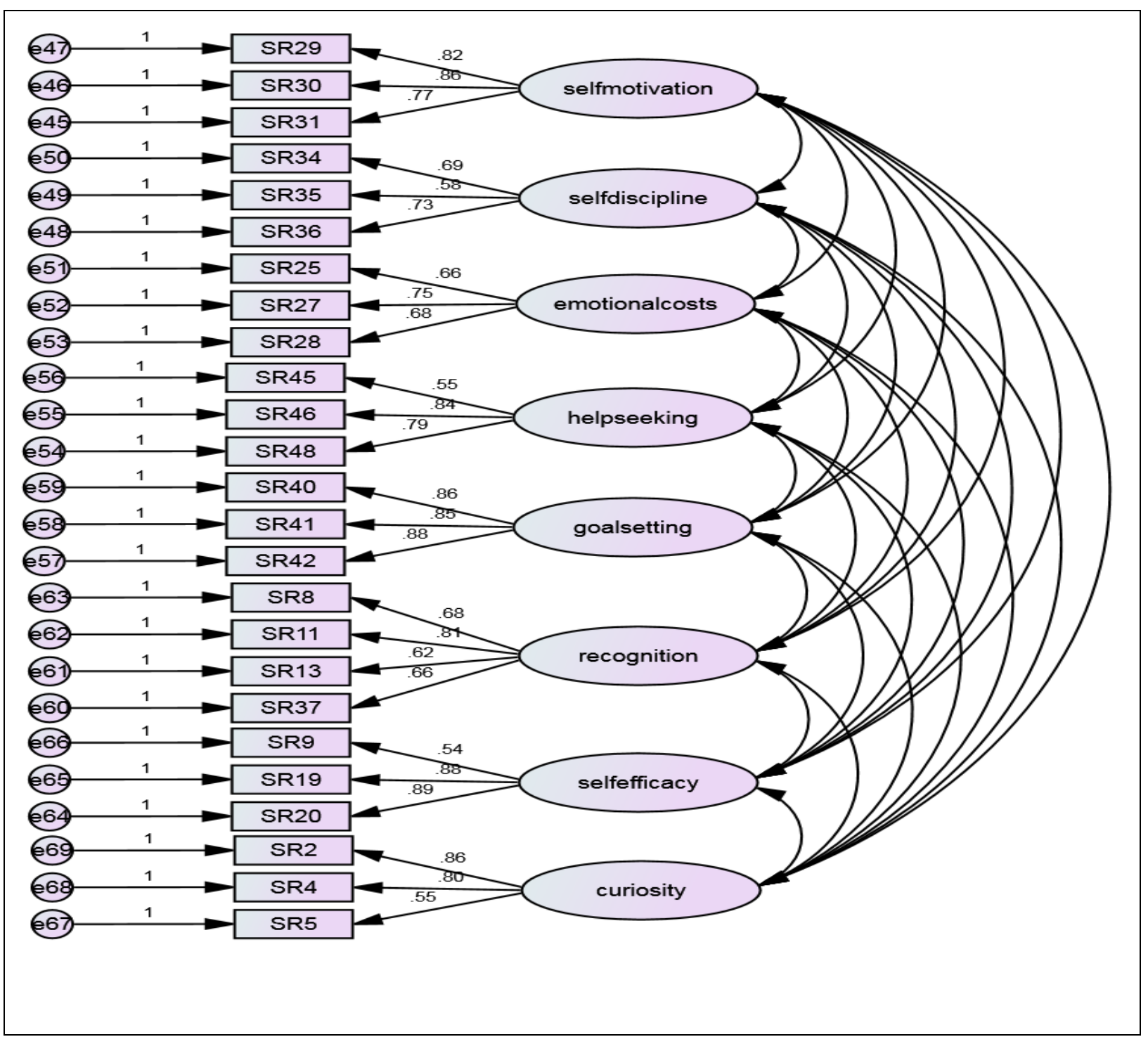

Figure 1. Confirmatory factor analysis (CFA) results for the eight-factor Self-Regulation Foreign Language Learning model

As shown in Figure 1, testing of the model for this group yielded a marginally good fit as indicated by the following criteria: $(\chi 2 / \mathrm{df}=4,17, \mathrm{RMSEA}=.072, \mathrm{CFI}=.96, \mathrm{GFI}=.93)$. The reliability for this scale as calculated by Cronbach's alpha was found .87, which indicated that the items had high internal consistency.

\section{Discussion}

The primary goal of this study was to develop and validate an instrument to evaluate university students' self-regulation competences while learning a foreign language within the framework of SEL. In line with this goal, numerous statistical processes were carried out. As a result, it was found out that self-regulation within the framework of SEL was a 
multidimensional construct that caused self-differentiation. As for the analyses, Principal component analysis of the SRFLLS yielded an eight-factor structure: Recognition of Strengths and Emotions, Self-Efficacy, Emotional Costs, Self-Motivation, Self-Discipline, Goal-Setting, Help-Seeking and Curiosity. The confirmatory factor analysis on the 25 -item version showed acceptable fit and its Cronbach's Alpha coefficient for the whole scale was satisfactory $(\alpha: 0.87)$ with the subscales ranging from .70 to .90 .

Regarding the effects of gender differences on university students' self-regulation competences, the results of the study showed that female students were more aware of selfregulation competences than male students in language learning. It was revealed that female students are more disciplined to achieve their goals, they seek help when they need to overcome the problems and they are more curious about learning new things to improve themselves. The results show consistency with Tseng, Liu and Nix's study (2017). In their study, they found out that female students were more controlled in strategy use than male students in language learning. They also added that girls were better than boys in emotion, awareness and boredom control.

It is worth mentioning that the findings of this study reiterate the fact that self-regulation language learning should include not only language learning strategies or motivational factors but also social and emotional competences. However, this current study does not include all these strategies as it is limited with the responses of university students in one part of Turkey. With a larger sample of students from other cities or countries, the results will be more generalized and more validated. There is also one thing with the scale is the lack of empirical data examining its validity in term of individual differences such as age, and the school they graduated from. Keeping all these things in mind, it is believed that this scale would be helpful for teachers, researchers and even students who try to develop their self-regulation language learning competences. However, it is not sufficient to observe students' self-regulation competences only with one instrument. Multiple methods of data collection including classroom observation, think alouds, and teacher/student interviews would depict students' progress better in self-regulation. 


\section{Conclusion}

Self-regulated foreign language learning is still an under-researched area with the framework of SEL. It is possible to search a broad range of topics in this field. In today's conditions, the new technological developments are available for each student so it is impossible for parents and teachers to ignore the use of technology in children's foreign language learning. Undoubtedly, in such case, there is a need to promote learners' selfregulatory and SEL skills as they are not aware of their own self-regulation competences while learning a foreign language. Therefore, it is believed that this instrument will be useful for individuals who are in need of a valid appraisal of their self-regulation competences in terms of foreign language learning such as solving problems about social emotional development, obtaining a better understanding of self or others, finding the reasons for their poor academic performance, making use of the power of technology and so on. Moreover, students will find a chance to identify their strengths and weaknesses, which will improve their self-regulation competences with the framework of SEL. By this way, they will maximize their learning and accomplish their goals. All in all, it is hoped this research will provide some guidance for those interested in exploring self-regulation, and contribute to a clearer understanding of the selfregulation foreign language learning within the framework of SEL. This study also showed that gender has an effect on self-regulatory competences so as a future research it is important to resolve the gender gap in self-regulation foreign language learning.

\section{References}

Bandura, A. (1986). Social foundations of thought and action: A social cognitive theory. Englewood Cliffs, NJ: Prentice-Hall.

Bandura, A. (1994). Self-efficacy. In V. S. Ramachaudran (Ed.), Encyclopedia of human behavior (Vol. 4, pp. 71-81). New York: Academic Press. (Reprinted in H. Friedman [Ed.], Encyclopedia of mental health. San Diego: Academic Press, 1998).

Chamot, A. (2014). Developing Self-Regulated Learning in the Language Classroom. Knowledge, Skills and Competencies in Foreign Language Education (pp. 78-88). Singapore: Proceedings of the Sixth International CLS Conference (CLaSIC) 
Collaborative for Academic, Social, and Emotional Learning (2003). Safe and sound: An educational leader's guide to evidence-based social and emotional learning (SEL) programs. Chicago, IL: Author.

CASEL (2013). 2013 CASEL guide: Effective social and emotional learning programs. Chicago, IL: Author. Retrieved from http://casel.org/guide/

Coryn, C. L. S., Spybrook, J. K., Evergreen, S. D. H., \& Blinkiewicz, M. V. (2009). Development and evaluation of the Social-Emotional Learning Scale. Journal of Psychoeducational Assessment, 27(3), 283-295.

Dornyei, Z. (2003). Questionnaires in second language research: Construction, administration and processing. Mahwah, NJ: Erlbaum

Dörnyei, Z. (2005). The psychology of the language learner: Individual differences in second language acquisition. Mahwah, NJ: Lawrence Erlbaum.

Durlak, J.A., Weissberg, R., Dymnicki, A.B., Taylor, R.D., \& Schellinger, K.B. (2011). The impact of enhancing students' social and emotional learning: A meta-analysis of school based universal interventions. Child Development, 82 , 405-432.

Greenberg, M.T., Weissberg, R.P., O’Brien, M.U., Zins, J.E., Fredericks, L., Resnik, H., \& Elias, M. (2003). Enhancing school-based prevention and youth development through coordinated social, emotional, and academic learning. American Psychologist, 58, 466474 .

Hall, J.K., Vitanova, G., \& Marchenkova, L. (Eds.). (2005). Dialogue with Bakhtin on Second and Foreign Language Learning: New Perspectives. Mahwah, NJ: Lawrence Erlbaum

Hair, JH., Black, WC., Babin, BJ., \& Anderson, RE. (2010) Multivariate data analysis, 7th ed. Pearson Prentice Hall, Englewood Cliffs

Halle, T. G., \& Darling-Churchill, K. E. (2016). Review of measures of social and emotional development. Journal of Applied Developmental Psychology, 45, 8-18

Kagan, S.L., Moore, E., \& Bredekamp, S. (Eds.) (1995). Reconsidering children's early learning and development: Toward shared beliefs and vocabulary. Washington, DC: National Education Goals Panel. 
Oxford, R. L. (2011). Teaching and researching language learning strategies. London, UK: Longman

Payton, J. W., Wardlaw, D. M., Graczyk, P. A., Bloodworth, M. R., Tompsett, C. J., \& Weissberg, R. P. (2000). Social and emotional learning: A framework for promoting mental health and reducing risk behavior in children and youth. Journal of School Health, 70(5), 179-185

Ramirez, A.G. (1995). Creating contexts for second language acquisition. New York: Longman.

Schunk, D.H., \& Zimmerman, B.J. (1998). Self-regulated learning: From teaching to selfregulated practice. New York: Guilford Press.

Tseng, W., Liu, H., \& Nix, J. (2017). Self-regulation in language learning: Scale validation and gender effects. Perceptual and Motor Skills, 124(2), 531-548. doi: $10.1177 / 0031512516684293$

Wolters, C. (2010). Self-Regulated Learning and the 21st Century Competences. Houston: Department of Educational Psychology, University of Houston, 1-27.

Zimmerman, B. J. (1990). Self-regulated learning and academic achievement: An overview. Educational Psychologist, 25(1), 3-17. doi: 10.1207/s15326985ep2501_2

Zimmerman, B. J. (2002). Becoming a self-regulated learner: An overview. Theory Into Practice, 41, 64-70. 
